\title{
A case report of ectopic pregnancy in a caesarean scar
}

\author{
Bharath Reddy $\mathrm{G}^{1}$, Venkatram Reddy $\mathrm{K}^{2^{*}}$, Rama Krishna Reddy $\mathrm{G}^{3}$, R S M oorthy \\ ${ }^{1}$ Postgraduate, ${ }^{2}$ Professor and HOD, ${ }^{3}$ Professor, ${ }^{4}$ Professor, Department of Radiodiagnosis, SVS Medical College and Hospital, \\ Mahaboobnagar, Telangana State, INDIA. \\ Email: vrkuchukulla@gmail.com
}

$\underline{\text { Abstract }}$

\begin{abstract}
Caesarean scar pregnancy (CSP) is the rarest locations for an ectopic pregnancy and incidence is increasing due to increasing number of cesarean sections. Delay in diagnosis can lead to significant maternal morbidity and mortality. We report a case of a 28-years-old lady, para 2, (both by cesarean section) and with a viable 12 weeks intrauterine pregnancy. Open laparoscopy suspected the diagnosis. At Laparotomy, the amniotic sac with a viable fetus was found attached to the cesarean section scar and partially protruding through a small rupture. The cyst removed, and ruptured injury repaired, hence preserving the uterus and future fertility.

Key Words: Caesarean section, ectopic pregnancy, cesarean scar pregnancy.
\end{abstract}

*Address for Correspondence:

Dr. Venkatram Reddy K, Professor and HOD, Department of Radiodiagnosis, SVS Medical College and Hospital, Mahaboobnagar, Telangana State, INDIA.

Email: vrkuchukulla@gmail.com

Received Date: 23/12/2017 Revised Date: 18/01/2018 Accepted Date: 14/02/2018

DOI: https://doi.org/10.26611/1013521

\begin{tabular}{|l|l|}
\hline \multicolumn{2}{|c|}{ Access this article online } \\
\hline Quick Response Code: & Website: \\
\hline & www.medpulse.in \\
\cline { 2 - 3 } & \\
\hline
\end{tabular}

\section{INTRODUCTION}

In 1978 Larson and Solomon studied and reported an ectopic pregnancy in the cesarean scar. Ectopic pregnancy in the cesarean scar is one of the rarest of all ectopic pregnancies ${ }^{1}$. According to Jurkovic D et al., 2003 the incidence of scar ectopic has increased day by day due to increase in some cesarean deliveries and the prevalence is estimated approximately $1: 1800^{2}$. Caesarean scar ectopic defined as when blastocyst implants on a previous Caesarean scar. Early detection, diagnosis, and management of the problem can do by using ultrasound or sonography. Early detection can delay the maternal mortality and morbidity and also improves the outcome by allowing preventions of future fertility ${ }^{3}$.

\section{CASE REPORT}

We are reporting a rare case of a 28-year-old G2P3 female with a history of one prior cesarean section. Current pregnancy was diagnosed by ultrasound at three months gestation with a report showing 12 weeks viable intrauterine pregnancy. Later reported an episode of minimal painless vaginal bleeding. Six days then said to the emergency department with acute abdominal pain with no vaginal bleeding. On examination, she was pale, tachycardic, and hypotensive. Abdomen examination showed generalized tenderness with signs of peritonitis. Her hemoglobin was $6 \mathrm{gm} \%$. On bimanual examination, cervix pointed upward; uterus was bulky, retroverted and bilateral fornices were free with no tenderness. On investigation, routine blood and urine investigations were standard. On admission, the B-HCG level was $7118 \mathrm{IU} / \mathrm{L}$, and after 48 hours B-HCG value was 8108 IU/L, which showed less than doubling. Transvaginal ultrasound revealed empty uterine cavity with clearly defined endometrium, the irregular small gestational sac-like structure of six weeks seen in lower uterine segment anteriorly with no cardiac activity. The cervical canal was empty and adnexa normal (figure 1). On Doppler examination, the hyperechoic rim of choriodecidual reaction with excessive vascularity suggestive of cesarean scar ectopic pregnancy. These findings confirmed on 
MRI-pelvis which showed a poorly defined heterogenous signal intensity space occupying lesion of $30 \times 23 \mathrm{~mm}$ seen in myometrium extending from the endometrial cavity with complete disruption of the junctional zone; it was reaching up to serosa, no defined invasion of the uterine wall seen. The patient planned for laparotomy. Intraoperative findings; soft vascular mass is seen at the site of the previous scar (Figure 2). An incision given over bulge and products of conception gently removed. It was communicating with the uterine cavity, edges of scar tissue were excised and freshened, gentle uterine curettage is done. Tissue was sent for histopathological examination and diagnosis of Caesarean scar ectopic pregnancy was confirmed.

\section{DISCUSSION}

Caesarean scar pregnancy (CSP) is one of the rare forms of ectopic pregnancies where the gestational sac wholly or partially implanted within a previous cesarean section scar. The gestational sac is separated from the endometrial cavity and surrounded by the myometrium and the fibrous tissue of the injury. The diagnosis of this type of ectopic pregnancy is challenging, and false adverse determination can lead to significant complications. The pregnancies with previous cesarean section have increased the risk of placenta praevia, placental abruption, placenta accreta, percreta as well as ectopic pregnancies in future. There are various theories which explain the etiology and mechanism of Caesarean ectopic pregnancy, the most accepted one is blastocyst invade into the myometrium through a microscopic dehiscent tract, which may be due to previous uterine surgery like Caesarean section, manual removal of placenta, etc. ${ }^{3}$. As per another theory in the absence of prior uterine surgery, Caesarean ectopic pregnancy can occur due to trauma did in assisted reproduction techniques ${ }^{4}$. The most common clinical presentation of Caesarean ectopic pregnancy is painless vaginal bleeding without any specific clinical signs. For its diagnosis endovaginal ultrasonography and color flow Doppler is very helpful ${ }^{5,6}$. MRI has an essential role when sonography is equivocal or inconclusive before therapy or intervention. There should be differentiation of Caesarean scar pregnancy from cervical pregnancy. To differentiate from a cervical pregnancy, in trans vaginal sonography no myometrium between the gestational sac and bladder must see, because the gestational sac grows into the anterior portion of the isthmus ${ }^{7}$. To determine whether a Cesarean Scar Pregnancy (CSP) has occurred, USG in the sagittal position can be used to indicate a transparent uterine cavity and an empty cervical canal ${ }^{8}$. Various case reports of patients with Caesarean scar ectopic pregnancy even in the presence of bleeding, supports our management as the surgical option ${ }^{4}$. This includes elective laparotomy and excision of the gestational mass. The benefit of surgery is less recurrence because of the resection of the old scar, with a new uterine closure. Other is a shorter follow-up period ${ }^{9,10,11}$. In another study with Caesarean scar pregnancy cases, surgical excision of the scar considered as crucial management and help to prevent recurrence ${ }^{7}$. There are no universal treatment guidelines for caesarean scar pregnancy. Hence, in these women issues concerning early detection are of utmost importance, and it is the corner-stone to reduce serious complications related to the cesarean scar pregnancy across all three trimesters ${ }^{12}$. In conclusion, CSP is increasing due to increasing number of cesarean sections. Prompt diagnosis and treatment of the condition require considerable expertise and high index of clinical suspicions to reduce associated morbidity and mortality. The management of CSP is not well established, but a conservative treatment of the uterus is feasible early in pregnancy. Thus, it is essential that early and accurate diagnosis of Caesarean scar pregnancy obtained to avoid complications and preserve fertility.
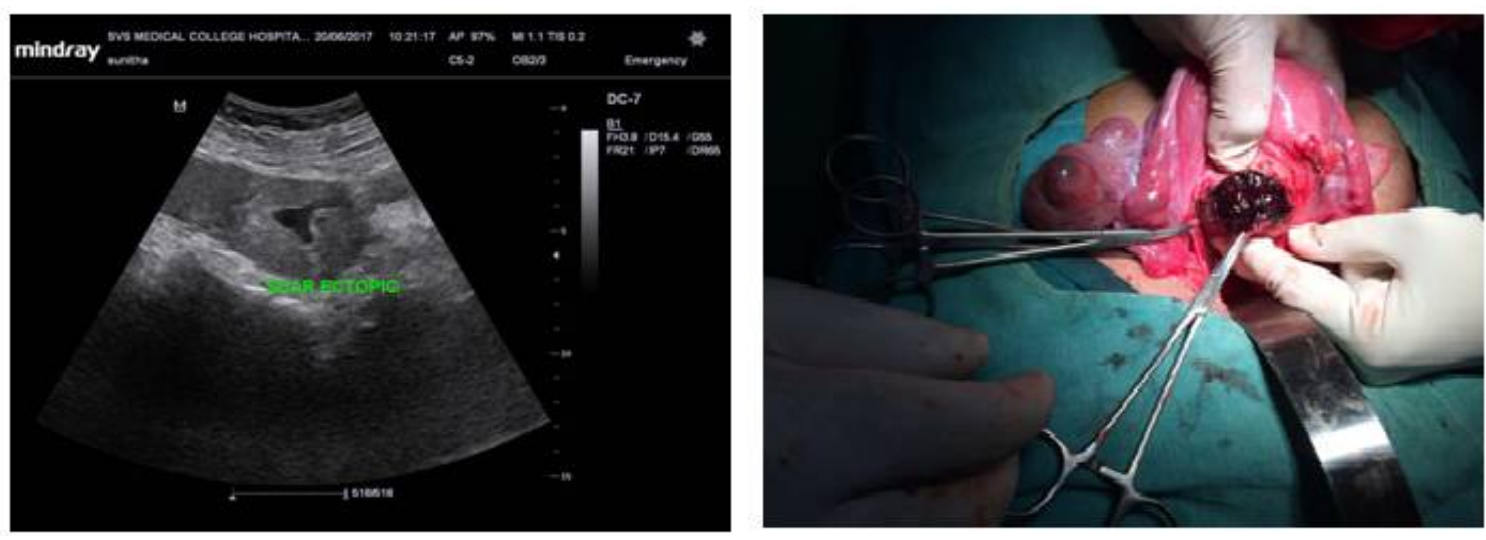

Figure 1: Ultrasound image-Caesarean scar pregnancy

Figure 2: Intraoperative-Caesarean scar pregnancy 


\section{REFERENCES}

1. Seow KM, Hwang JL, Tsai YL, Huang LW, Lin YH, Hsieh BC. Subsequent pregnancy outcome after conservative treatment of a previous Caesarean scar pregnancy. Acta Obstetriciaet Gynecologica Scandinavica. 2004; 83(12):1167-72.

2. Jurkovic D, Hillaby K, Woelfer B, Lawrence A, Salim R, Elson CJ. First-trimester diagnosis and management of pregnancies implanted into the lower uterine segment Caesarean section scar. Ultrasound in Obstetrics and Gynecology. 2003; 21(3):220-27.

3. Cignini P, Giorlandino M, Caserta L, Dominici L, Giorlandino C. The importance of early diagnosis in Caesarean scar pregnancy. J Prenat Med. 2007; 1(2):29_ 31.

4. Aich R, Solanki N, Kakadiya K, Bansal A, Joshi M, Nawale A. Ectopic Pregnancy in caesarean section scar: A case report. Radiology Case Reports. 2015; 10 (4): 6871.

5. Fylstra DL, Pound-Chang T, Miller MG, Cooper A, Miller KM. Ectopic pregnancy within a Caesarean delivery scar: a case report. American Journal of Obstetrics and Gynecology. 2002; 187(2):302-04.

6. Timor-Tritsch IE, Monteagudo A. Unforeseen consequences of the increasing rate of caesarean deliveries: early placenta accreta and caesarean scar pregnancy, a review. Am J Obstet Gynecol. 2012 Jul; 207(1):14-29.

7. McKenna DA, Poder L, Goldman M, Goldstein RB. Role of sonography in the recognition, assessment, and treatment of caesarean scar ectopic pregnancies. J Ultrasound Med, 2008; 27:779-83.

8. Wang CJ, Yuen LT, Yen CF, Lee CL, Soong YK. Threedimensional power Doppler ultrasound diagnosis and laparoscopic management of a pregnancy in a previous caesarean scar. J Laparoendosc. Adv Surg Tech 2004; 14:399-402.

9. Peng KW, Lei Z, Xiao TH, Jia FG, Zhong WX, Gao Y, Shen BX, Xie JW. First trimester caesarean scar ectopic pregnancy evaluation using MRI. Clin Radiol 2014; 69:123-9.

10. Rotas MA, Haberman S, Levgur M. Caesarean scar ectopic pregnancies: aetiology, diagnosis and management. Obstet Gynecol 2006; 107:1373-81.

11. Qian ZD, Guo QY, Huang LL. Identifying risk factors for recurrent caesarean scar pregnancy: a case- control study. Fertil Steril, 2014; 102:129-134.

12. Timor-Tritsch IE, Monteagudo A, Santos R. The diagnosis, treatment, and follow-up of Caesarean scar pregnancy. Am J Obstet Gynecol. 2012; 207:44.e1-13.

Source of Support: None Declared Conflict of Interest: None Declared 